$\mathbb{A}$
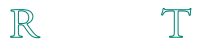

Dorota Gregorowicz

University of Silesia in Katowice

\title{
PRIMATE MIKOŁAJ PRAŻMOWSKI AND THE UNWELCOME PAPAL LEGATION IN POLAND-LITHUANIA (1668-69)*
}

\begin{abstract}
The article presents the reasons for refusing to receive the papal legation of Pope Clement IX in the matter of John Casimir Vasa's abdication (1668) and, especially, the subsequent royal election (1669), by the Catholic Primate of the Polish-Lithuanian Commonwealth, Mikołaj Prażmowski. Prażmowski’s refusal to receive the legation has been overlooked in the literature on the subject so far. The author, on the basis of the diplomatic dispatches of the apostolic nuncios and on their instructions, will analyse the problematic relations of Prażmowski with papal diplomats, and explain why the papal legation ended in fiasco. The researcher concludes that the fiasco of papal legation was another clear indication of the Papacy's lack of sufficient leverage in the post-Westphalian world, as it was fundamentally weakened by the deep divisions between the Catholic powers of France and the Habsburgs, which Westphalia had signally failed to resolve. Nowhere was this more apparent than in Poland-Lithuania, where the battle between Catholic supporters of the Habsburgs and France over the succession had profoundly divided the republic.
\end{abstract}

Keywords: Mikołaj Prażmowski, papal legation, seventeenth century, Polish-Lithuanian Commonwealth, Catholic Church, Clement IX

* The paper was created as a result of research carried out under the Sonatina 2 project entitled Holy See towards the crisis of sovereignty of John Casimir Vasa and Michael Korybut Wiśniowiecki's election (1660-1669) (Polish: Stolica Apostolska wobec kryzysu wtadzy królewskiej Jana Kazimierza Wazy oraz elekcji Michata Korybuta Wiśniowieckiego (1660-1669), project no. 2018/28/C/HS3/00176, financed by the National Science Centre, Poland (Narodowe Centrum Nauki). 
The purpose of the present article is to illustrate the reasons for refusing to receive the papal legation ${ }^{1}$ of Pope Clement IX in the matter of John Casimir Vasas abdication (1668) and, especially, the subsequent royal election (1669), by the Catholic Primate of the Polish-Lithuanian Commonwealth, Mikołaj Prażmowski.

After the arrival to Rome of official notification of the decision of John Casimir Vasa to abdicate, the cardinal protector of the Polish-Lithuanian Commonwealth, ${ }^{2}$ Virginio Orsini, suggested to the Pope that a legate a latere would be sent to Poland-Lithuania to guarantee the peaceful course of the forthcoming interregnum and to support the election of a king favourable to the Catholic Church. This idea was based on the earlier appeals of John Casimir, to Antonio Pignatelli, the apostolic nuncio in the Commonwealth (and, from 1691, Pope Innocent XII). The suggestion of a papal legation was then seriously considered by Clement IX, who consulted it with Pignatelli and the newly appointed nuncio to Poland-Lithuania, Galeazzo Marescotti.

The problem of Prażmowski's refusal to receive the subsequent papal legation has been overlooked in the literature on the subject. On the basis of the diplomatic dispatches of the apostolic nuncios and on their instructions, I will analyse the problematic relations of Prażmowski with papal diplomats, and explain the why the papal legation ended in fiasco.

\section{THE DECISION TO SEND A LEGATION}

The most important elements of the papal policy of neutrality in the early modern era were mediation and arbitration. The Holy See's mediation

${ }^{1}$ Let me recall that legates a latere were the highest papal dignitaries in quality of diplomats, exceeding by their prestige the apostolic nuncios and legati nati (honorary title assigned to certain archiepiscopal seats). See: Bernard Barbiche, Ségolène De Dainville-Barbiche, 'Les légats a latere en France et leurs facultés aux XVI et XVII siècles', Archivum Historiae Pontificiae, 23 (1985), pp. 93-165.

${ }^{2}$ In the seventeenth century the cardinals' 'protection' of Catholic states developed as a further arena for diplomatic negotiations of the early modern Papacy. See: Joseph Wodka, Zur Geschichte der nationalen Protektorate der Kardinäle an der römische Kurie (Innsbruck and Leipzig: F. Rauch, 1938); Stefano Andretta, L'arte della prudenza. Teorie e prassi della diplomazia nell'Italia del XVI e XVII secolo (Rome: Biblink, 2006), pp. 47-48. 
meant the intervention of papal diplomacy in a conflict in which it did not participate directly to facilitate negotiations between the parties in dispute. ${ }^{3}$ Alain Tallon described this characteristic political attitude of the early modern Papacy as active neutrality. ${ }^{4}$ According to Tallon and Heinz Schilling, this was a clever diplomatic strategy by the Papacy, which used peace missions to advance the Church's confessional aims in the newly emerging early modern system of European and global relations, despite its lack of military or economic leverage. ${ }^{5}$

The idea of a papal intervention through a legate a latere to Poland-Lithuania, which had been shaken by internal conflicts, the threat of royal abdication and the prospect of a new interregnum, was born in the early spring of 1668. In this case, one can talk of a peacemaking intervention rather than formal diplomatic mediation.

The Papacy attentively observed the dynamically changing political situation in the Commonwealth after the Swedish Deluge and the peace of Oliwa (1660), as well as all attempts to reform its political system that appeared since the 1650s. The last, difficult years of John Casimir's reign have been marked by several defeats in international politics, the king's constant attempts to push through the projects of vivente rege election, as well as internal tensions that have been revealed with full force in

${ }^{3}$ See: Lucien Bély, 'La médiation diplomatique au XVII siècle et au début du XVIII siècle', in Armées et diplomatie dans l'Europe di XVII siècle. Actes du Colloque de 1996. Bulletin nr 16, Paris 1992, pp. 129-47 (p. 129).

${ }^{4}$ The word 'international' is used here as contractual and simplifying. See: Alain Tallon, 'Conflicts et médiationes dans la politique internationale de la papauté, in Papato e politica internazionale nella prima età moderna, ed. by Maria Antonietta Visceglia (Rome: Viella, 2013), pp. 117-30 (pp. 118-19).

${ }^{5}$ Wojciech Tygielski, Rzymu do Rzeczypospolitej. Studia z dziejów nuncjatury apostolskiej w Polsce, XVI i XVII w. (Warsaw: Wydawnictwa Fundacji "Historia pro Futuro", 1992), p. 61; Tallon, 'Les missions de paix de la papauté au XVI ${ }^{\mathrm{e}}$ siècle', in Guerres et paix en Europe centrale aux époques moderne et contemporaine. Mélanges d'histoire des relations internationales offerts à Jean Bérenger, ed. by Daniel Tollet (Paris: Presses de l'Université Paris-Sorbonne, 2003), pp. 165-80 (p. 168): 'La politique de médiation entre les Etates catholiques correspondait à la vocation du pape comme chef spirituel et à ses intérêts comme prince temporel, et il est bien difficile de séparar l'un de l'autre. [...] Pour s'imposer comme médiateurs, les papes devaient être capables de faire pression sur les Etates concernés. Malgré sa faiblesse militaire, Rome disposait d'atouts et savait les faire valoir'. See: Id., Conflicts et médiationes, pp. 117-30 (pp. 117-19). 
the Lubomirski's rebellion (rokosz). ${ }^{6}$ The diplomats of the Holy See supported all the projects of the royal election procedure reform and thus securing the succession in Poland-Lithuania. In this way, they wanted to ensure the Commonwealth's maintenance in the orbit of political and confessional influence of Papacy, especially considering the inevitability of conflict between Christian Europe and the Ottoman Empire. For this reason, the Papacy was hostile to all the abdication projects of John Casimir, which appeared in the first months of 1667. Although the Holy See clearly opposed itself to the Vasa's abdication, it could not remain indifferent to the political struggle in the Commonwealth and towards diplomatic efforts of the European monarchies regarding the inevitable election of a new king. In Rome, all energies were spent to make John Casimir retain his crown, and preferably, after the death of Queen Marie Louise Gonzaga, to make him enter into a new marriage. However, because the time pressed, it was necessary to undertake a simultaneous political action in case of a possible interregnum. ${ }^{7}$

From the mid-1650s, strongly influenced by his wife Marie Louise, John Casimir remained under the French impact. Louis XIV's faction in the Polish-Lithuanian Commonwealth got strengthened. The Vasa never explicitly opposed himself to political intrigues aimed at depriving him of the crown that had been weighing him for years. John Casimir was convinced of his inability to reign and of the reluctance of the nobility towards him. He also suffered health problems. ${ }^{8}$ The first plans for

${ }^{6}$ About the escalation of the political crisis of the Commonwealth expressed in the form of a rokosz see: Witold Kłaczewski, W przededniu wojny domowej w Polsce. Walka sejmowa z lat 1664-1665 (Lublin: UMCS, 1984); Mirosław Nagielski, Rokosz Jerzego Lubomirskiego w 1665 roku (Warsaw: Trio, 1994); Stanisław Płaza, Rokosz Lubomirskiego (Warszawa: Krajowa Agencja Wydawnicza, 1996); Witold Kłaczewski, Jerzy Sebastian Lubomirski (Wrocław: Zakład Narodowy im. Ossolińskich, 2002); Mirosław Nagielski, Druga wojna domowa w Polsce: $z$ dziejów polityczno-wojskowych Rzeczypospolitej u schytku rządów Jana Kazimierza Wazy (Warsaw: Neriton, 2011); Igor Kraszewski, 'Rokosz Lubomirskiego. Tło konfliktu wewnętrznego w rzeczypospolitej XVII wieku', in Bitwa pod Mątwami. Historia i pamięć, ed. by Tomasz Łaszkiewicz (Inowrocław: Polskie Towarzystwo Historyczne Oddział w Inowrocławiu, 2017), pp. 13-35.

7 Dorota Gregorowicz, 'Stolica Apostolska wobec abdykacji Jana Kazimierza 1667-1668', Kronika Zamkowa. Roczniki, 68, no. 2 (2015), 139-63.

${ }^{8}$ Maciej Matwijów, 'Geneza abdykacji Jana Kazimierza Wazy 1662-1668', Czasopismo Zaktadu Narodowego imienia Ossolinskich, 11 (2000), 79-136 (pp. 80-82). 
the abdication in favour of Henri Jules de Bourbon, Prince of Condé, appeared in 1662, following the embracing of a constitution prohibiting the king's further efforts in favour of the vivente rege election projects. ${ }^{9}$ New serious plans regarding the French succession appeared only after the end of Lubomirski's rokosz. John Casimir and Louis XIV entered into an agreement ratified in Vincennes on 1 October 1666, according to which the king decided to abdicate during the forthcoming Sejm in 1667. Yet, the project failed due to the missing Lubomirski's support. ${ }^{10}$ Nevertheless, at that time the plans of the royal abdication were no longer a secret both among the nobility and at the European courts. ${ }^{11}$ They were also not overlooked in the Roman Curia. In January 1667, the apostolic nuncio in the Commonwealth, Antonio Pignatelli, pointed out that the only way out of the political crisis in Poland-Lithuania was the French protection to guarantee military subsidies against Muscovy and Ottoman Empire. In return, it was necessary to ensure the succession for the Prince of Condé, who was then put forward as the main candidate for the Vasa's succession. ${ }^{12}$ Meanwhile, on 10 May 1667, Marie Louise Gonzaga made her life. The death of the queen made John Casimir feel the weight of the crown even more. ${ }^{13}$ However, the Roi Très-chrétien's

${ }^{9}$ More on the vivente rege election projects and abdication plans from 1662-1666: Stefania Ochmann, Sejmy lat 1661-1662. Przegrana batalia o reforme ustroju Rzeczypospolitej (Wrocław: Wydawnictwo Uniwersytetu Wrocławskiego, 1977), pp. 3-23, 202, 208-09; Matwijów, 'Geneza abdykacji', pp. 79-136 (pp. 80, 83-96).

${ }^{10}$ Wiktor Czermak, 'Ostatnie lata życia Jana Kazimierza', in Ostatnie lata Jana Kazimierza, ed. by Adam Kersten (Warszawa: Państwowy Instytut Wydawniczy, 1972, pp. 259-447 (p. 265); Zbigniew Wójcik, Jan Kazimierz Waza (Wrocław: Zakład Narodowy im. Ossolińskich, 1997), pp. 199-200; Matwijów, 'Geneza abdykacji', pp. 79-136 (pp. 98-103); Adam Przyboś, Michat Korybut Wiśniowiecki 1640-1673 (Kraków: Universitas, 2007), p. 29.

${ }^{11}$ Wójcik, Jan Kazimierz, p. 198.

${ }^{12}$ Letter from Antonio Pignatelli to Giacomo Rospigliosi, Warsaw, 4 I 1667, Archivio Apostolico Vaticano, Segreteria di Stato (hereafter cited as: AAV, Segr. di Stato), Nunz. Diverse 151, fol. 1r. Cf. Gregorowicz, 'Stolica Apostolska wobec abdykacji', pp. 139-63 (pp. 141-42).

13 Tadeusz Wasilewski, Ostatni Waza na polskim tronie (Katowice: Śląsk, 1984), p. 258; id., Jan Kazimierz (Warszawa: Zamek Królewski, 1985), p. 59; Wójcik, Jan Kazimierz, p. 192-94, 198; Matwijów, 'Geneza abdykacji', pp. 79-136 (pp. 105-06); Zbigniew Hundert, Wojsko koronne w walce stronnictwa malkontentów z ugrupowaniem dworskim 1669-1673 (Oświęcim: Napoleon V, 2014), p. 74. 
plans towards the Commonwealth have changed. In July 1667, in the face of the War of Devolution and French aggression against the Spanish Netherlands, Louis XIV allied with Philip William of Neuburg. In exchange for his support in the conflict, the king of France offered support for the project of marrying one of the Neuburg's daughters with widowed John Casimir, persuading the monarch not to abdicate. Also, Sweden and Brandenburg endorsed these plans, while John Casimir accepted them with reluctance. ${ }^{14}$ However, as early as October 1667, Philip William of Neuburg abandoned the project of espousing his daughter to the Vasa, concluding an agreement with France and Brandenburg according to which Louis XIV was to support Neuburg's aspirations for succession in the Commonwealth. In December 1667, a new treaty was concluded, on the basis of which the Roi Très-chrétien's was to support the aspirations of Philip William in Poland-Lithuania in exchange for the accession of Neuburg to the Rhine Pact and for supporting France in the conflict over the Netherlands. In such way, Louis XIV temporarily gave up support for French princes' succession in the Commonwealth. From now on, Europe began to speak loudly about the new election upcoming in Poland-Lithuania. ${ }^{15}$

The Sejm of $1668^{16}$ began on 24 January and lasted until 17 March. Its main goals were to regulate the military affairs (especially army's payments), to determine issues related to the policy towards the Ottoman

${ }^{14}$ Letter from Antonio Pignatelli to Giacomo Rospigliosi, Warsaw, 24 V 1667, AAV, Segr. di Stato, Pol. 82, fol. 179. Cf. Czermak, 'Ostatnie lata', pp. 259-447 (pp. 270-73); Wasilewski, Ostatni Waza, pp. 259-61; id., Jan Kazimierz, pp. 60-61; Matwijów, 'Geneza abdykacji', pp. 79-136 (pp. 100, 108); Janusz Dąbrowski, 'Senat koronny wobec abdykacji Jana Kazimierza’, Zeszyty Naukowe Uniwersytetu Jagiellońskiego. Prace Historyczne, 127 (2000), pp. 39-58 (p. 40).

${ }^{15}$ Czermak, 'Ostatnie lata', pp. 259-447 (pp. 276-77); Wasilewski, Ostatni Waza, p. 262; id., Jan Kazimierz, s. 61; Matwijów, 'Geneza abdykacji', pp. 79-136 (pp. 112-14); Dąbrowski, 'Senat koronny', pp. 39-58, (p. 41).

${ }^{16}$ It was an extraordinary sejm, convened on 15 November 1667 as a result of the difficult internal and external situation of the Polish-Lithuanian Commonwealth. See: Matwijów, Ostatnie sejmy przed abdykacja Jana Kazimierza 1667 i 1668 (Wrocław: Polska Akademia Nauk, Zakład Narodowy im. Ossolińskich, 1992); Ochmann-Staniszewska, Zdzisław Staniszewski, Sejm Rzeczypospolitej za panowania Jana Kazimierza Wazy. Prawo - doktryna - praktyka, I (Wrocław: Wydawnictwo Uniwersytetu Wrocławskiego, 2000), pp. 527-72. 
Empire to be undertaken, and to solve some problems related to the parliamentary procedures. Anti-royal attitude prevailed among the nobility that arrived to Warsaw. It was demanded to expel foreign ambassadors and the constitution forbidding a royal abdication was being projected. Also an establishment of a confederation against a new election was planned, under the threat of the Noble Host. The Sejm was finally broken off by chorazzy of Sandomierz, Marcin Dembicki. No resolutions were taken. ${ }^{17}$ The apostolic nuncio at the Polish-Lithuanian court, Antonio Pignatelli, obtained a royal audience on 20 March 1668, immediately after the conclusion of the parliamentary dispute. John Casimir complained to Pignatelli about the difficult situation in the realm, suggesting that it would be beneficial if a high-ranked papal representative came as a neutral mediator in the continuing internal conflicts in Poland-Lithuania. The king suggested for such a mission the person of the former apostolic nuncio at his own court, cardinal Pietro Vidoni, ${ }^{18}$ with whom he had maintained good relations. In May 1668, John Casimir addressed a similar request to Virginio Orsini, the Commonwealth's cardinal protector, asking once again whether the Pope would be willing to send a legate to Poland-Lithuania, to mediate in the internal conflicts between rival political factions, and to promote the establishment of a new network of alliances directed against the Ottoman Empire, which was threatening war against the Commonwealth. ${ }^{19}$ Once again, John Casimir suggested the person of cardinal Vidoni. ${ }^{20}$

${ }^{17}$ Czermak, 'Ostatnie lata', pp. 259-447 (pp. 290, 295); Wasilewski, Ostatni Waza, pp. 264-65; id., Jan Kazimierz, p. 63; Wójcik, Jan Kazimierz, p. 200; Matwijów, 'Geneza abdykacji', pp. 79-136 (p. 122); Przyboś, Michat Korybut, p. 29.

${ }^{18}$ Letter from Antonio Pignatelli to Giacomo Rospigliosi, Warsaw, 21 III 1668, AAV, Segr. di Stato, Pol. 82, fol. 262r. About Pietro Vidoni's nunciature in PolandLithuania (1652-1660) see: Katarzyna Wiszowata-Walczak, Pietro Vidoni - nuncjusz $w$ Rzeczypospolitej 1652-1660 (Ph. D. thesis).

${ }^{19}$ Letter from John Casimir Vasa to Virginio Orsini, Warsaw, 30 V 1668, in Elementa ad Fontium Editiones, T. III, Repertorium Rerum Polonicarum ex Archivo Orsini in Archivo Capitolino Romae, I pars, ed. by Wanda Wyhowska de Andreis (Rome: Istitutum Historicum Polonicum, 1961), nr 571, p. 62; Letter from Giacomo Rospigliosi to Antonio Pignatelli, Rome, 20 VI 1668, AAV, Segr. di Stato, Nunz. Diverse 27, fol. 33r (copy dated 30 VI 1668: AAV, Segr. di Stato, Germ. 185, fols 14v-15r).

${ }^{20}$ Letter from Giacomo Rospigliosi to Antonio Pignatelli, Rome, 20 VI 1668, AAV, Segr. di Stato, Nunz. Diverse 27, fol. 33r (copy dated 30 VI 1668: AAV, Segr. di Stato, Germ. 185, fols 14v-15r). 
From Rome, cardinal Secretary of State Giacomo Rospigliosi asked nuncio Pignatelli for an opinion regarding the idea:

[We] will gladly hear whether you consider the mission of the legate to be convenient, as well as whether the Person of Mons. Cardinal Vidoni might be considered suitable, since, in such instances, the Apostolic Minister must be confident of each of the Parties, or at least not wary of any of them. ${ }^{21}$

According to Rospigliosi, Orsini supported the project of sending Vidoni to Poland-Lithuania as a papal legate a latere. Clement IX, however, was cautious about both the mission as a whole, and Vidoni himself. As the cardinal Secretary of State wrote:

it seems to His Holiness that a decision solving this point requires mature consideration, given the current state of affairs. [...] So it would be praiseworthy if Your Signeurity, who is right there, in the time close to the abdication of His Majesty, in which it is likely that the inclinations of many [nobles] will appear clearer and freer, gave all the lights that you would consider appropriate in this matter, also signifying your [own] opinion about the mission of the legate, as well as the reasons and conveniences, that there can be with regard to the matter of whether to send him, or not, and whether Mons. Cardinal Vidoni would be universally accepted. ${ }^{22}$

With regard to the arrival in Rome of the official information concerning John Casimir's final decision to abdicate, ${ }^{23}$ Orsini personally

${ }^{21}$ Ibid.: 'Si udirà volentieri da lei, se stimi conveniente la missione del Legato e quello, che quanto alla Persona del Sig. Cardinal Vidoni, possa esservi da considerare, dovendo in simili occorrenze il Ministro Apostolico essere confidente à ciascuna delle Parti, ò almeno non diffidente ad alcuna'.

${ }^{22}$ Letter from Giacomo Rospigliosi to Galeazzo Marescotti, Rome, 21 III 1668, AAV, Segr. di Stato, Pol. 82, fols 25-26: 'A Sua Santità pare che il risolvere sopra questo punto richieda molta maturità per lo stato presente delle cose costì. [...] Onde sarà bene, che Vostra Signoria la quale si trova sul luogo et in tempo, nel quale per l'abdicatione seguita ò vicina di Sua Maestà, è verisimile, che più chiare e più libere appariscano le inclinationi di molti dia quà tutti lumi che ella stimarà opportuni nella materia, significando anche il suo parere circa la missione del Legato, et le ragioni, e convenienze, che possono esservi di mandarlo, ò nò, e se il Sig. C. Vidoni fosse per essere accetto universalmente'.

${ }^{23}$ It had place on 13 June 1668, with the official letter of John Casimir Vasa directed to the Pope. See: Gregorowicz, 'Stolica Apostolska wobec abdykacji', pp. 139-63 (pp. 147-48). 
reminded Clement IX of the idea of sending a legate a latere to PolandLithuania. ${ }^{24}$ The cardinal Secretary of State, Giacomo Rospigliosi, decided to consult the newly-appointed apostolic nuncio to the Commonwealth, Galeazzo Marescotti, asking whether such a mission would make sense considering the necessity of maintaining papal neutrality towards the forthcoming royal election, whether the legate would be accorded due respect in loco, and whether cardinal Pietro Vidoni would be an appropriate candidate, universally accepted by the nobility. Similar questions were once again submitted to Antonio Pignatelli, an experienced papal diplomat, who had moved in the meantime from Warsaw to Vienna.

Clement IX soon became more and more convinced of the necessity of sending his representative to Poland-Lithuania, on account of the inevitable abdication of John Casimir and of the forthcoming election. Rospigliosi wrote to Marescotti on 14 July 1668 that 'Our Father is inclined to agree to the mission of the legate with regard to the serious matter of the new King's election. A formal declaration will follow soon'. ${ }^{25}$ In preparing to send a legate, the Pope wished to raise the rank and authority of his current diplomatic representation in Poland-Lithuania and, consequently, increase papal influence on the election. ${ }^{26}$ Officially though, such a mission was aimed at solving the factional struggle causing the internal crisis of the Commonwealth and ensuring that a Catholic prince would be elected to the Polish-Lithuanian throne.

With regard to the advantages of the legation project, the papal side emphasized the high political and moral authority of a legate a latere, as well as his richer diplomatic experience in comparison to an ordinary apostolic nuncio. The success of the planned embassy could guarantee

${ }^{24}$ Letter from Giacomo Rospigliosi to Antonio Pignatelli, Rome, 30 VI 1668, AAV, Segr. di Stato, Germ. 185, fols 14v-15r; Letter from Giacomo Rospigliosi to Galeazzo Marescotti, Rome, 30 VI 1668, AAV, Segr. di Stato, Pol. 82, fols 25-26.

${ }^{25}$ Letter from Giacomo Rospigliosi to Galeazzo Marescotti, Rome, 14 VII 1668, AAV, Segr. di Stato, Pol. 82, fol. 31v: 'Inclinando Nostro Signore alla missione del Legato costà per l'affare sì grave della nuova elettione del Rè ne seguirà facilmente in breve la dichiaratione'.

26 Ibid. 
the Papacy lasting glory in the Polish-Lithuanian Commonwealth, strengthen its influence among the local Episcopate, as well as assure noble gratitude for the maintenance of inner peace and for the protection of Catholicism. On the other hand, it was appreciated that it would be extremely difficult to organize such a mission in the short time available. Moreover, even if the legate managed to arrive in time for the forthcoming election, he would have very little time to inform himself about the problems involved or to establish a proper political and informational network. Before the election, which was initially planned for autumn 1668, the legate would have little opportunity to negotiate with the most prominent senators of the Commonwealth. ${ }^{27}$ Even if Vidoni were appointed, and was able to use his contacts among the senatorial elites established during his previous mission (1652-60), this would not secure the support of the noble masses, who, it was rightly predicted in Rome, would prove decisive during the forthcoming election. ${ }^{28}$

Clement IX was also concerned at the possibility, albeit a remote one, of the Tsarevich's elevation to the Polish-Lithuanian throne. The legate would be therefore charged with preventing the election of the Muscovite candidate, despite the real fear that he would be forced to witness the triumph of the Orthodox in Poland-Lithuania. In consideration of the Tsarevich's aspirations, in Orsini's opinion, there was a risk that organizing a papal legation would mean 'to go voluntarily in bocca al rospo. ${ }^{29}$

In Rome, the opinion of papal diplomats present in loco seemed to be considered crucial, although ultimately, despite their positive opinions with regard to the legation, it turned out to be a fiasco. Pignatelli wrote positively concerning the idea of sending Vidoni: 'I believe that this mission could not be more convenient, and I also maintain my opinion that Cardinal Vidoni's person could not become a reason of suspicion

${ }^{27}$ Letter from Galeazzo Marescotti to Giacomo Rospigliosi, Warsaw, 25 VII 1668, AAV, Segr. di Stato, Pol. 82, fols 294r, 296v.

${ }^{28}$ Letter from Galeazzo Marescotti to Giacomo Rospigliosi, Warsaw, 25 VII 1668, AAV, Segr. di Stato, Pol. 82, fol. 302v.

${ }^{29}$ Letter from Virginio Orsini to Cristoforo Masini, Rome, 15 XI 1668, Archivio Capitolino, Archivio Orsini, I Serie, Corrispondenza familiare, diplomatica e amministrativa, vol. 247, fols 219-22r. 
for any of the Parties'. ${ }^{30}$ In the meantime, Marescotti emphasized that the legation should be a clear sign of the Papacy's neutrality. If the papal envoy failed to reconcile the rival factions in Poland-Lithuania, he would endanger the authority of the Holy See and its credentials as a neutral arbitrator and mediator in Europe. ${ }^{31}$ Marescotti therefore expressed certain doubts:

It should be also considered that since these peoples are so jealous of their freedom; God only knows if they would welcome the arrival of a Cardinal Legate, fearing perhaps, that the Holy See wishes to lay its hands on their political interests, in which they profess not to recognize any superiority. ${ }^{32}$

Finally, the nuncio was also concerned about the reaction of those who wished to preserve the political primacy and ecclesiastical authority of the Primate - the legato nato, ${ }^{33}$ the ambitious Mikołaj Prażmowski. Since no papal legate had been sent to Poland-Lithuania for decades, it was not entirely clear how relations between the papal envoy and the Primate were supposed to develop. A major conflict over hierarchy and

${ }^{30}$ Letter from Antonio Pignatelli to Giacomo Rospigliosi, Vienna, 22 VII 1668, AAV, Segr. di Stato, Germ. 185, fol. 116: 'Crederei non potesse essere, che convenevole l'accennata missione, come tengo anche per fermo, che la persona del Sig. Cardinal Vidoni non possa essere punto diffidente ad alcuna delle Parti'.

${ }^{31}$ Letter from Galeazzo Marescotti to Giacomo Rospigliosi, Warsaw, 25 VII 1668, AAV, Segr. di Stato, Pol. 82, fols 294r, 296v.

32 Ibid., fols 297v-98r. "Potrebbe anche riflettersi a che vivendo questi Popoli gelosissimi della loro libertà; Dio sà se prendessero in buona parte la venuta di un Cardinal Legato, temendo forse, che la Santa Sede volesse porre le mani ne i loro interessi politici, ne quali professano di non riconoscere alcun superiore".

${ }^{33}$ Since the Middle Ages, the Primates have enjoyed special prerogatives in the area of ecclesiastical jurisdiction, resulting from their right to legation and from papal privileges (not always historically documented). Gniezno became the Primate's capital as a result of the necessity to determine the supremacy of the local Church after the creation of the second Archbishopric in Halicz (1375), which was then transferred to Lviv (1412). However, this happened not on the basis of a papal document, but via facti, thanks to the support of the Polish Episcopate and King Władysław Jagiełło. It was only Leon X in 1515 to officially confirm the prerogatives of Archbishops of Gniezno as Primates and legati nati in the papal bull Pro excellenti, addressed to Jan Łaski. See: Wojciech Góralski, 'Instytucja prymasów w Kościele katolickim', in Prymasi i prymasostwo $w$ dziejach państwa i narodu polskiego, ed. by Wiesław Jan Wysocki (Warsaw: Instytut Wydawniczy Pax, 2002), pp. 10-15 (pp. 13-14). 
precedence was to be expected with regard to the coronation ceremony of the new monarch, even in the smallest aspects, such as clothing. ${ }^{34}$ Possible protocol difficulties with the Primate worried both the apostolic nuncios, the papal Secretariat of State, as well as Orsini. ${ }^{35}$

Rome responded politely to the request of John Casimir to send a legate, without presenting a clearly positive response. In this way, the Pope wished to express his hope that the king would abandon his abdication plans. Clement IX expressed his concern about the consequences of an interregnum and new election. ${ }^{36}$ In July 1668, by which time it was accepted that the abdication was inevitable, new papal briefs were sent to the nuncio. Rospigliosi told Marescotti that he should begin diplomatic activity with regard to the election, stating 'that the Legate will then be able to continue more authoritatively but perhaps not early enough, since it will take time for him to arrive'. ${ }^{37}$ However, when the abdication of John Casimir became a fact, at the beginning of September 1668, Rospigliosi expressed papal gratitude towards Marescotti for his insight concerning the legate's mission to Poland-Lithuania, nonetheless admitting that:

His Holiness has always believed that sending the Legate would bring little success and be of even less profit because of the difficulties that [the Pope] feared would arise even before they were listed by Your Seigneurity. Nevertheless, he estimated it a duty in consideration of the serious threat to the Catholic religion, as well as an extraordinary demonstration for the satisfaction of the World; that with regard to the outcome of the forthcoming election, no [possible] prejudice against our Most Holy Faith could be attributed to a fault on the part of His Holiness. ${ }^{38}$

${ }^{34}$ Letter from Galeazzo Marescotti to Giacomo Rospigliosi, Warsaw, 25 VII 1668, AAV, Segr. di Stato, Pol. 82, fols 298-99.

35 Letter from Virginio Orsini to Ludovico Fantone, Rome, 23 IX 1668, Archivio Capitolino, Archivio Orsini, I Serie, Corrispondenza familiare, diplomatica e amministrativa, vol. 247, fols $111 \mathrm{v}-13 \mathrm{r}$.

${ }^{36}$ Letter from Virginio Orsini to John Casimir Vasa, Rome, 28 VII 1668, Archivio Capitolino, Archivio Orsini, I Serie, Corrispondenza familiare, diplomatica e amministrativa, vol. 247, fol. 37.

${ }^{37}$ Letter from Giacomo Rospigliosi to Galeazzo Marescotti, Rome, 14 VII 1668, AAV, Segr. di Stato, Pol. 82, fol. 31v: 'Che il Legato sarà per portar poi più autorevolmente mà forse non tanto à tempo richiedendo la venuta di lui qualche lunghezza'.

${ }^{38}$ Letter from Giacomo Rospigliosi to Galeazzo Marescotti, Rome, 1 IX 1668, AAV, Segr. di Stato, Pol. 82, fol. 47: 'Succedendo nell'elettione del nuovo Rè alcun 
Hence, before the royal abdication, no real political steps regarding the legation were taken on either side. When the real chance to prevent the royal abdication had disappeared, papal promptness and declarations regarding the organization of the cardinal legate's mission ceased.

It should be emphasized that the papal involvement in the affairs of the Commonwealth and the project of sending a legate a latere were unofficial, although known to noble society and international public opinion. For example, on the basis of secret information provided by the French ambassador in Poland-Lithuania Pierre de Bonzy, bishop of Béziers, the matter of the legation was raised in letters written by Christina, the former queen of Sweden, to cardinal Decio Azzolini. ${ }^{39}$

\section{PRIMATE'S PLAYING THE LATE VERSUS PAPAL LACK OF CONVICTION}

Following the abdication of John Casimir on 16 September 1668, a new interregnum formally began. According to traditional practice, governing authority was assumed by the interrex: the Archbishop of Gniezno and Primate of the Kingdom. Thus the leadership in any negotiations concerning a papal legation to the Commonwealth was taken over from the king by Mikołaj Prażmowski.

Following the death of Queen Marie Louise in 1667, nuncio Pignatelli pointed out Prażmowski and the Great Chancellor of Lithuania Krzysztof Pac as the main politicians supporting the king in his intent to abdicate. $\mathrm{He}$ also accused them of receiving financial revenues from the French court and of manipulating John Casimir's political attitude. ${ }^{40}$ This was true, the Primate became involved in the French politics as early as 1656

pregiudizio alla nostra Santissima fede, non potesse mai attribuirsi à difetto veruno di premura per la parte di Sua Santità.

${ }^{39}$ Letter from Christine Vasa to Decio Azzolino, Hamburg, 1 VII 1668, in Christine de Suède et le cardinal Azzolino: Lettres inédites (1666-1668) avec une introduction et des notes par le Baron de Bildt, ed. by Carl Nils Daniel Bildt (Paris: Plon, 1899), p. 461.

${ }^{40}$ Letter from Antonio Pignatelli to Giacomo Rospigliosi, Warsaw 27 VII 1667, AAV, Segr. di Stato, Pol. 82, fols 190-92r. Cf. Letter from Antonio Pignatelli to Giacomo Rospigliosi, Warsaw 24 VIII 1667, AAV, Segr. di Stato, Pol. 82, fols 199-200r, Matwijów, 'Geneza abdykacji', pp. 79-136 (pp. 88-91). 
by the French ambassador in the Commonwealth, Antoine de Lumbres. Afterwards, Marie Louise won him for the realisation of her plans to link Poland-Lithuania with French politics through the French succession in the Commonwealth. Already in February 1659, Prażmowski presented himself enthusiastic about the candidacy of Henri Jules de Bourbon, Prince of Condé and about all the royal election reform projects that at that time had been proposed by Giulio Mazzarini. During the 1660s, he repeatedly signed commitments to support a French candidate to the Polish-Lithuanian crown, being regularely financed by the French court. After the death of the queen, Mikołaj Prażmowski became de facto a head of the French faction in the Commonwealth. ${ }^{41}$

In Rome, the Primate's pro-French sympathies were quite well known, which constituted a problem since relations between Clement IX and Louis XIV were cool. Cardinal Secretary of State wrote about this in response to a report from the nuncio concerning a supposed declaration of support for Philip William of Neuburg, the candidate favoured by Louis, by Mikołaj Prażmowski and Jan Sobieski in November 1668. Rospigliosi drily noted, considering being a person standing on the sidelines of the Polish-Lithuanian political scene, that 'such declarations can be very false and hide purposes very different from appearances'. ${ }^{42}$ Indeed, the truth was that the Primate had a negative attitude towards the Neuburg's candidacy, constantly insisting on Prince of Condé. ${ }^{43}$

In order to convey in Rome his aversion to the project of papal legation indirectly, Prażmowski used the mediation of the French court and of the local apostolic nuncio, Pietro Bargellini. Meanwhile, in court circles in the Polish-Lithuanian Commonwealth, he continued to represent himself as open to the arrival of the legate, offering him accommodation in his own palace. Conscious of these contradictions, cardinal Rospigliosi directed Marescotti's attention to the two-faced

${ }^{41}$ Przyboś, 'Prażmowski, Mikołaj', Polski Stownik Biograficzny, XVIII/3, 1984, pp. 382-89 (pp. 383-86) (hereafter cited as: PSB XXVIII/3).

${ }^{42}$ Letter from Giacomo Rospigliosi to Galeazzo Marescotti, Rome, 24 XI 1668, AAV, Segr. di Stato, Pol. 82, fol. 69v: 'Simili dichiarationi possono esser molto fallaci e nasconder fini assai diversi dall'apparenze'.

43 PSB XXVIII/3, pp. 382-89 (p. 386). 
nature of Prażmowski and to his political games. ${ }^{44}$ The nuncio was supposed to avoid any conflicts with the Primate, in consideration of the need to defend the Catholic interests during the upcoming election. ${ }^{45}$

By the end of October 1668, in Rome, it was felt that there was no real sense in sending a papal legate to Poland-Lithuania. At the papal court, the royal election in Poland-Lithuania was expected at the beginning of 1669. It was feared, therefore, that the legate would not arrive on time, that he would not be allowed to participate directly in the election Sejm, and, even if admitted, the nobility would not be interested in negotiating with him. Rospigliosi stated that Clement IX had decided to follow in the footsteps of his predecessors and not to send a legate a latere to the election. ${ }^{46}$ At that time, serious objections to the plan were also articulated by Orsini. ${ }^{47}$ In the meantime, Rospigliosi asked Marescotti not to announce the papal decision, 'to be able to enjoy the benefit of time and full freedom to deliberate in the most appropriate way'. ${ }^{48}$

Meanwhile, Prażmowski continued to delay sending a courier with a request for a papal legation. First, he justified himself with the necessity of further consultations with the Episcopate, the need for the approval of secular senators, and finally, with the desire to obtain the universal approval of the draft of the letter to the Pope. ${ }^{49}$ On 12 November, the

${ }^{44}$ Letter from Giacomo Rospigliosi to Galeazzo Marescotti, Rome, 6 X 1668, AAV, Segr. di Stato, Pol. 82, fol. 58r.

${ }^{45}$ Letter from Giacomo Rospigliosi to Galeazzo Marescotti, Rome, 6 X 1668, AAV, Segr. di Stato, Pol. 82, fol. 60v: 'Con Mons. Arcivescovo di Gnesna è necessaria somma destrezza convenendo caminar con doppio riguardo di non pregiudicare del carattere ch'ella sostiene né alle convenienze degli affari più grandi che hà hora bisogno di trattare'.

${ }^{46}$ Letter from Giacomo Rospigliosi to Galeazzo Marescotti, Rome, 6 X 1668, AAV, Segr. di Stato, Pol. 82, fol. 63.

${ }^{47}$ Letter from Virginio Orsini to Cristoforo Masini, Rome, 3 XI 1668, in Elementa ad Fontium Editiones, T. X. Repertorium Rerum Polonicarum ex Archivo Orsini in Archivo Capitolino Romae, III pars, ed. by Wyhowska de Andreis, (Romae: Istitutum Historicum Polonicum, 1964), nr 337, p. 74 (hereafter cited as: EFE X).

${ }^{48}$ Letter from Giacomo Rospigliosi to Galeazzo Marescotti, Rome, 6 X 1668, AAV, Segr. di Stato, Pol. 82, fol. 63: 'Per poter frà tanto godere il benefitio del tempo et la piena libertà di deliberare nel miglior modo che convenga'.

49 Letter from Galeazzo Marescotti to Giacomo Rospigliosi, Warsaw, 14 XI 1668, AAV, Segr. di Stato, Pol. 82, fol. 437. Abbot Baski reported on behalf of his patron 
Bishop of Cracow, Andrzej Trzebicki, informed Marescotti that the Senate had discussed the papal legation. It had been decided to ask the Primate officially to send a special courier to the Pope asking him to appoint a cardinal legate for to attend the forthcoming election Sejm. ${ }^{50}$ The nuncio himself had repeatedly and unsuccessfully tried to convince Mikołaj Prażmowski on this matter. ${ }^{51}$ Nevertheless, on 21 November, Marescotti reported further delays in sending a courier to Rome on behalf of the Primate, which resulted from his constant excuses regarding the necessity of waiting for the establishment of the exact date of the election by the convocation Sejm..$^{52}$

There was a deep conviction in the Roman Curia that Prażmowski did not have any real intention of asking for a legate's mission to the Commonwealth, and that all his previous declarations bore no signs of sincerity. ${ }^{53}$ The nuncio commented on Prażmowski's behaviour as follows: 'I repeatedly told him that the request will be [made] too late, but as I can see that he persists in his purpose, I tell no more to

Prażmowski, that the letter of the Primate regarding the issue of papal legation to the Commonwealth could not be considered a universal request of the Kingdom, nor even of the Polish-Lithuanin clergy, 'because none of these Universities competed in it as would have been required' (orig. 'perche nessuna di queste Università vi è concorsa come si richiederebbe'.) It raised additional doubts about the meaning of the entire papal initiative. See: Letter from Giacomo Rospigliosi to Galeazzo Marescotti, Rome, 26 I 1669, AAV, Segr. di Stato, Pol. 82, fol. 93v.

${ }^{50}$ Letter from Andrzej Trzebicki to Galeazzo Marescotti, Warsaw, 12 XI 1668, AAV, Segr. di Stato, Pol. 82, fol. 647.

${ }^{51}$ Letter from Galeazzo Marescotti to Andrzej Trzebicki, Warsaw, 12 XI 1668, AAV, Segr. di Stato, Pol. 82, fol. 647r.

52 Letter from Galeazzo Marescotti to Giacomo Rospigliosi, Warsaw, 21 XI 1668, AAV, Segr. di Stato, Pol. 82, fol. 446r: 'Monsignore Arcivescovo di Gnesna dice di volere aspettare à spedire il corriero con l'instanza del Card. Legato quando sarà stabilito dalla Convocatione il tempo della Dieta di elettione. Io più volte gli hò fatto dire che sarà troppo tarda l'istanza, mà perche vedo, che egli persiste nel suo proposito, non gli dico altro, e lo lascio fare'. After the king's decease (or abdication), the Archbishop of Gniezno and Primate of the Kingdom, invoked the so-called convocation sejm. During this assembly, the nobility had to decide the way, date, and place of the future election. See: Władysław Konopczyński, 'Konwokacje', in Studia historyczne ku czci Stanistawa Kutrzeby, vol. I (Cracow: Nakł. Komitetu, 1938), p. 247.

${ }^{53}$ Letter from Giacomo Rospigliosi to Galeazzo Marescotti, Rome, 8 XII 1668, AAV, Segr. di Stato, Pol. 82, fol. 73v. 
him, and I let him carry on. ${ }^{54}$ A few days later, however, Marescotti expressed his suspicions:

The tenuity of the pretext, presented by Monsignor the Archbishop of Gniezno for not sending a courier with the request for a mission of the Cardinal Legate, that is that he wishes to inform [the Pope] at the same time about the date on which the election Sejm will be inaugurated, that could have been done also later, made me suspect that there may still be some other political purposes. ${ }^{55}$

He suggested that the decisive factor was Prażmowski’s jealousy towards the legate's political and ecclesiastical prerogatives, resulting from his position in the hierarchy of papal diplomacy. In brief, the Primate did not want to let the papal representative arrive, so as 'not to tarnish his own splendour with the coming of a superior authority'. 56

In the nuncio's opinion, Prażmowski was negatively perceived by the majority of noblemen. Marescotti blamed him entirely for delaying or even preventing the arrival of a cardinal legate. At the same time, however, he assured the Curia that he would not dare to publicly criticize the Primate or oppose his position and actions in Poland-Lithuania, so as not to weaken the Catholic position in the Commonwealth before the election. ${ }^{57}$

During the convocation Sejm, after establishing the date of the inauguration of the election assembly, the apostolic nuncio immediately sent his secretary to the Primate to urge Prażmowski to send a courier to the Pope in the matter of the legation. Although another five months would pass before the election, in Marescotti's opinion, the cardinal legate should reach the Commonwealth as soon as possible. Yet Prażmowski still refused to send letters to Rome, arguing that the date of convening the election Sejm still could change in the course

${ }^{54}$ Letter from Galeazzo Marescotti to Giacomo Rospigliosi, Warsaw, 21 XI 1668, AAV, Segr. di Stato, Pol. 82, fol. 446r: 'Io più volte gli hò fatto dire che sarà troppo tarda l'istanza, mà perche vedo, che egli persiste nel suo proposito, non gli dico altro, e lo lascio fare'.

55 Letter from Galeazzo Marescotti to Giacomo Rospigliosi, Warsaw, 28 XI 1668, AAV, Segr. di Stato, Pol. 82, fol. 455r.

${ }^{56}$ Ibid., fol. 455v: 'Per non offuscare il suo lustro con la venuta di Personaggio maggiore di sé'.

57 Letter from Galeazzo Marescotti to Giacomo Rospigliosi, Warsaw, 7 XI 1668, AAV, Segr. di Stato, Pol. 82, fols 426-28. Cf. PSB XXVIII/3, pp. 382-89 (pp. 384-85). 
of the convocation assembly. ${ }^{58}$ During its deliberations, the nuncio visited the Bishop of Kuyavia, Kazimierz Florian Czartoryski, asking him for his opinion regarding the arrival of the papal legation in the Polish-Lithuanian Commonwealth for the time of the interregnum after John Casimir Vasa's abdication. Czartoryski, however, was convinced, relying on information received earlier on behalf of the Primate, that the legation's project would indeed not be finalised. ${ }^{59}$

Nevertheless, while Marescotti continued to put pressure on Prażmowski to send a courier to Rome asking for a legation, in early November, the Curia distanced herself from the plan. Contrary to the belief in Rome that the new monarch would be elected in the winter of $1668 / 1669$, the convocation assembly decided to postpone the election to the early summer of 1669 . Those few months had significant consequences with regard to the plan of sending a papal legation. Orsini suspected, quite naively, that the postponement of the election Sejm was aimed at obtaining papal approval for the organization of the legate's mission. ${ }^{60}$ Marescotti decided, therefore, to take the initiative in this matter and to continue his efforts to secure acceptance for the plan, and requested new instructions with regard to the postponement of the election.

By the end of the year there was still no appeal to Rome regarding the issue of papal legation from either the Polish-Lithuanian Episcopate or the states of the Commonwealth. As Rospigliosi wrote in mid-December

Not having yet seen the Courier who was supposed to be sent by Monsignor the Archbishop of Gniezno with the request for the mission of an Apostolic Legate, it seems that he has more interest in the appearance than the effect. ${ }^{61}$

${ }^{58}$ Letter from Galeazzo Marescotti to Giacomo Rospigliosi, Warsaw, 5 XII 1668, AAV, Segr. di Stato, Pol. 82, fol. 481r.

59 Ibid., fol. $481 \mathrm{v}$.

${ }^{60}$ Letter from Virginio Orsini to Cristoforo Masini, Rome, 3 I 1669, in EFE X, nr 357, p. 79.

${ }^{61}$ Letter from Giacomo Rospigliosi to Galeazzo Marescotti, Rome, 15 XII 1668, AAV, Segr. di Stato, Pol. 82, fol. 78r: 'Non essendosi ancora veduto il Corriere che doveva spedirsi da Mons. Arcivescovo di Gnesna con l'istanza per la missione costà di un Legato Apostolico si era considerato anco qui ch'egli havesse più a cuore in ciò l'apparenza che l'effetto'. 
Rospigliosi emphasized that the Pope was willing to send his high-ranked diplomat to Poland-Lithuania, but he was discouraged by the attitude and lack of interest of the local Episcopate. ${ }^{62} \mathrm{He}$ now warned Marescotti that he would have to undertake all diplomatic activities on behalf of the Holy See during the election. ${ }^{63} \mathrm{He}$ again stressed that even if Prażmowski at last requested the legation in the very near future, the lack of time remaining for the election and the need to undertake preparations to organize the legate's mission, made it impossible to obtain papal agreement for it. ${ }^{64}$

On 19 December Marescotti informed Rome that:

I am told, that Monsignor the Archbishop of Gniezno did not ask for the Legate's mission with his last courier, indeed, that he has no real intention of writing, only answering me in that form to reassure me, and that within some time he will tell me that he has lost the letter, and thus he will pull me along, until it will be no longer possible for the Cardinal Legate to come. I do not believe it, and I suppose, that he wrote [the request], because he answered the same to me, as to Monsignors the Bishops of Cracow and of Chełm. ${ }^{65}$

${ }^{62}$ Ibid.; Letter from Giacomo Rospigliosi to Galeazzo Marescotti, Rome, 15 XII 1668, AAV, Segr. di Stato, Pol. 82, fol. 77v.

${ }^{63}$ Letter from Giacomo Rospigliosi to Galeazzo Marescotti, Rome, 8 XII 1668, AAV, Segr. di Stato, Pol. 82, fol. 73. In Rome it was admitted that 'what in the mind of His Holiness diminishes very much the concept of a Legate's [sending] necessity is the attention, prudence, and sagacity with which Your Signeurity fulfils his duties' (orig. 'Quello che nella mente di Sua Santità diminuisce anco molto il concetto della necessità di un legato è l'attenzione, prudenza, e sagacità con le quali Vostra Signoria adempie costì le sue parti'.) See: Letter from Giacomo Rospigliosi to Galeazzo Marescotti, Rome, 20 X 1668, AAV, Segr. di Stato, Pol. 82, fol. 63. Cardinal Secretary of State was right, Galeazzo Marescotti should be objectively considered one of the most prominent and politically involved representatives of the Holy See in the Polish-Lithuanian Commonwealth in the seventeenth century.

${ }^{64}$ Letter from Giacomo Rospigliosi to Galeazzo Marescotti, Rome, 8 XII 1668, AAV, Segr. di Stato, Pol. 82, fol. 73v.

${ }^{65}$ Letter from Galeazzo Marescotti to Giacomo Rospigliosi, Warsaw, 19 XII 1668, AAV, Segr. di Stato, Pol. 82, fol. 504r: 'Mi si dice, che Monsignore Arcivescovo di Gnesna non scrivesse l'ordinario passato per la missione del Legato, anzi, che né meno habbia intentione di scrivere, ma che facesse rispondere à me in quella forma per quietarmi, e che à suo tempo dirà essersi smarrita la lettera, e cosi tirare à lungo, finché non possa più venire il Card. Legato. Io non lo credo, e suppongo, che habbia 
The nuncio was right. Finally, on 12 December, Prażmowski decided to write to Orsini requesting the papal legation. He referred to earlier examples of papal legations to the Commonwealth, connected with the issues of interregnums and their consequences. ${ }^{66}$ It is significative that the Primate addressed his official request to Orsini, belonging to the French faction in the Sacred College of Cardinals and not to Clement IX himself. Above all, he motivated his appeal by the danger that a Muscovite candidate might be elected. Prażmowski tried to convince the Curia that about two-thirds of Polish-Lithuanian nobles were inclined to support the Tsarevich's aspirations. Yet, in Rome, this information was thought to be implausible. The Secretariat of State was well aware of the fact that the rumours regarding the Muscovite candidacy, reported by Prażmowski, were fictitious ${ }^{67}$ and that opposition to any aspirations of Muscovy to the Polish-Lithuanian throne was all but universal. In Rome, it was noticed that the Primate deliberately exaggerated the threat of a Muscovite candidacy to realise his own political projects ${ }^{68}$ and it was believed that his political game was meant to obtain papal support for French aspirations in the Commonwealth. ${ }^{69}$

The delay in the gathering of the election Sejm caused dissatisfaction in Rome. According to Rospigliosi, in any case, there was no more time to organize a legation, while postponing the election for late spring could only increase the Muscovite chances. ${ }^{70}$ Marescotti still seemed to believe, however, that in consideration of the postponement of the

scritto perché lo stesso, che hà fatto rispondere à me, hà detto alli Mons. Vescovi di Craccovia e di Culma'.

${ }^{66}$ Letter from Mikołaj Prażmowski to Virginio Orsini, s. 1., 12 XII 1668, AAV, Segr. di Stato, Pol. 82, fol. 91.

${ }^{67}$ Letter from Giacomo Rospigliosi to Galeazzo Marescotti, Rome, 29 XII 1668, AAV, Segr. di Stato, Pol. 82, fols 82v-83r.

${ }^{68}$ Letter from Giacomo Rospigliosi to Galeazzo Marescotti, Rome, 15 V 1669, AAV, Segr. di Stato, Pol. 82, fols 106v-07r.

${ }^{69}$ Letter from Virginio Orsini to Ludovico Fantone, Rome, 19 I 1669, in Elementa ad Fontium Editiones, T. XVIII. Collectanea e rebus Polonicis Archivi Orsini in Archivo Capitolino Romae, II pars, ed. by Wyhowska de Andreis (Romae: Istitutum Historicum Polonicum, 1968), nr 2, p. 5 (hereafter cited as: EFE XVIII).

${ }^{70}$ Letter from Giacomo Rospigliosi to Galeazzo Marescotti, Rome, 22 XII 1668, AAV, Segr. di Stato, Pol. 82, fol. 81v. See also: Letter from Giacomo Rospigliosi to Galeazzo Marescotti, Rome, 29 XII 1668, AAV, Segr. di Stato, Pol. 82, fol. 82. 
election Sejm to May 1669, the Pope might change his mind and decide to send one of his cardinals to the Commonwealth, so that Marescotti himself, uneasy with regard to his relations with Prażmowski, would not be forced to participate in the election. ${ }^{71}$ In particular, the nuncio was afraid of a ceremonial disagreement with the Primate during the celebrations of the election. According to Marescotti, Prażmowski would prefer not to appear (under the excuse of illness or indisposition) than to give way to the representative of the Holy See. In Marescotti's opinion, the only solution to the problem of precedence would be the arrival of a papal legate a latere, whose ceremonial priority was unquestionable. ${ }^{72}$

\section{CEREMONIAL CONSIDERATIONS}

Immediately after John Casimir's abdication, Prażmowski began to apply pressure on Marescotti to obtain papal confirmation of the decision regarding the sending of a cardinal legate to the Commonwealth. At that point, he stated that such a mission would be rather useless (It. superfluo)..$^{73}$ The nuncio warned Rospigliosi that the Primate did not recognize the ceremonial precedence of papal representatives in PolandLithuania. For this reason, Prażmowski intentionally avoided participating in the same ceremonies as diplomats of the Holy See, as was the case during the ceremonies mounted in connection with the abdication. ${ }^{74}$

${ }^{71}$ Letter from Galeazzo Marescotti to Giacomo Rospigliosi, Warsaw, 9 I 1669, AAV, Segr. di Stato, Pol. 82, fol. 529. In January 1669, the Nuncio informed the Curia about the usages of accepting earlier papal legations in the Polish-Lithuanian Commonwealth, citing examples of Cardinals Giovanni Francesco Commendone and Ippolito Aldobrandini. See: Letter from Galeazzo Marescotti to Giacomo Rospigliosi, Warsaw, 9 I 1669, AAV, Segr. di Stato, Pol. 82, fol. 518r.

${ }^{72}$ Letter from Galeazzo Marescotti to Giacomo Rospigliosi, Warsaw, 9 I 1669, AAV, Segr. di Stato, Pol. 82, fols 529-31.

${ }^{73}$ Letter from Giacomo Rospigliosi to Galeazzo Marescotti, Rome, 1 IX 1668, AAV, Segr. di Stato, Pol. 82, fol. 354r. Also Bishop of Cracow Andrzej Trzebicki, nevertheless belonging to the opposite political party, admitted to Nuncio Marescotti that he did not see any political necessity of the papal legation's arrival. See: Letter from Galeazzo Marescotti to Giacomo Rospigliosi, Warsaw, 19 IX 1668, AAV, Segr. di Stato, Pol. 82, fol. 361r.

${ }^{74}$ Letter from Galeazzo Marescotti to Giacomo Rospigliosi, Warsaw, 16 IX 1668, AAV, Segr. di Stato, Pol. 81, fol. 368. 
Officially though, the Archbishop of Gniezno declared himself ready to welcome a papal legate. One of Prażmowski's servants reported that the Primate presented himself prepared to accept a legate with all due honours, even more splendidly than during the latest mission of cardinal Flavio Chigi to the French court (1664) ${ }^{75}$ Nevertheless, Prażmowski advanced a series of possible protocol and ceremonial difficulties that such a legation might encounter in loco,

especially, that since Monsignor the Archbishop during an interregnum is Vice-King and Head of the Republic, he believes absolutely that his position neither permits him to make public visits, nor to return visits to anybody, nor to allow the Cardinal to hold and carry the elevated Cross. Indeed, he also expresses his opinion that the Commonwealth would desire that the Legate, sent to her by Our Master the Pope for the affair of the election, should reside far from Warsaw, and was guarded like other Ambassadors of Princes, apart from many other similar difficulties and differences that would be faced. ${ }^{76}$

Marescotti commented that from what he knew, at the time of the interregnum, the apostolic nuncios used to be treated differently from other ambassadors, and the cardinal legate all the more, examples of this were known from previous papal diplomatic missions to the Commonwealth. ${ }^{77}$

Prażmowski, even after sending an official request to Rome for a legate's mission, argued that he, as Primate, should enjoy ceremonial priority and the privilege of bringing the cross to the Senate's deliberations and during any public processions. ${ }^{78}$ According to the ceremonial

${ }^{75}$ Letter from Galeazzo Marescotti to Giacomo Rospigliosi, Warsaw, 22 VIII 1668, AAV, Segr. di Stato, Pol. 81, fol. 316r.

${ }^{76}$ Letter from Galeazzo Marescotti to Giacomo Rospigliosi, Warsaw, 13 VIII 1668, AAV, Segr. di Stato, Pol. 81, fol. 275r: 'In specie, che facendo esso Monsignor Arcivescovo in tempo d'Interregno la figura del Vice Rè, e Capo della Republica; crede che questa assolutamente non gli permetteria visitare publicamente, ne restituir Visita ad alcuno, ne il lasciare di tenere, e portare la Croce inalberata anco avanti il Cardinale, anzi che dubita, che la medesima Republica vorrà che detto Legato come inviato a lei da Nostro Signore per l'affare dell'elettione risieda fuori di Varsavia lontano, e con le guardie come gli altri Ambasciatori de Prencipi, e che si incontreranno molte altre simili difficoltà e differenze'.

77 Ibid.

${ }^{78}$ Letter from Galeazzo Marescotti to Giacomo Rospigliosi, Warsaw, 30 I 1669, AAV, Segr. di Stato, Pol. 82, fol. 550r. 
of Jacques de Stefaneschi, among the privileges of the papal legate, we can read: 'Attende tamen quod crux non portatura ante legatum nec ante nuntium'. ${ }^{79}$ The cross was an important ceremonial element in the early modern Polish-Lithuanian Commonwealth. Any political decision taken during Senate or Sejm deliberations used to sworn by the cross.

Marescotti also commented on Prażmowski's haughtiness by comparing the current political situation to events during the previous interregnum of 1648: 'From information obtained from Monsignor Fantuzzi thanks to the Canon my brother, I find that Monsignor de Torres was treated better during the past interregnum' ${ }^{80}$ In Rome, the ceremonial rivalry between papal diplomats and Prażmowski was feared, especially with regard to the forthcoming election Sejm. ${ }^{81}$ Rospigliosi informed nuncio Marescotti that from the part of the Roman Curia a search in the Archives of St. Peter had been carried out, more specifically in the correspondence of Giovanni De Torres to verify the circumstances of the nuncio's participation in the election of John Casimir in 1648. According to the reports rediscovered by the papal officials, the nuncio in the Senate received (on the day of his public audience) a place between the Archbishops of Gniezno (on the right side) and Lviv (on the left), quite far away from other bishops. That information was confirmed by Giacomo Fantuzzi, commissioner of the Apostolic Camera, who in 1648, as auditor of De Torres, had accompanied the nuncio personally during the deliberations of the election Sejm. Rospigliosi emphasized that there were other living witnesses of the events of that time: Prażmowski, Trzebicki and Jan Gembicki, Bishop of Płock.

Even in the most ancient times, the piety of the Republic of Poland and its worthy veneration for the Supreme Pontiff gave in the election Sejm, with even greater

${ }^{79}$ Marc Dykmans, Le Céremonial Papal de la Fin du Moyen Age à la Renaissance. II: De Rome en Avignon ou le Céremonial de Jacques Stefaneschi (Brussels: Institut Historique Belge de Rome, 1981), p. 500.

${ }^{80}$ Letter from Galeazzo Marescotti to Giacomo Rospigliosi, Warsaw, 17 X 1668, AAV, Segr. di Stato, Pol. 82, fol. 382r: 'Da alcune notitie ricavate costì da Monsignor Fantuzzi per mezzo del Canonico mio fratello ritrovo, che à Monsignor de Torres nel passato interregno furono usati molto maggiori trattamenti'.

${ }^{81}$ Letter from Virginio Orsini to Ludovico Fantone, Rome, 19 I 1669, in EFE XVIII, nr 2, p. 4. 
dignity, a place and prerogatives for the Apostolic Nuncios, and the Primates always wanted to prove themselves in such a spirit, especially honouring those who principally represented the Pope. ${ }^{82}$

Marescotti was supposed to adapt himself to ceremonial solutions from the previous election. In Rome, there were hopes that in the end they would not be challenged by the Primate. ${ }^{83}$ What was not known, however, was what to expect from Gembicki and Trzebicki, whether they would take the part of the Primate, or agree to the version of events presented by Giovanni de Torres and accept the papal appeal. ${ }^{84}$ The nuncio decided discreetly to investigate local feelings with regard to the ceremonial accompanying the election of John Casimir in 1648. He asked Trzebicki and Gembicki, as well as royal secretaries Cristoforo Masini and Girolamo Pinocci. None of them were supporters of Prażmowski. Thanks to their information, Marescotti could confirm that Giovanni de Torres enjoyed the most prestigious place in the Senate at the election Sejm, sitting between and above the two Archbishops. ${ }^{85}$

Marescotti received official papal letters that should have guaranteed him a prestigious place in the ceremonies of the upcoming election, in which Clement IX referred to the earlier cases of royal elections, especially that of 1648, when Giovanni de Torres assisted the election and the coronation of John Casimir. According to Rospigliosi, this correspondence was supposed to

force them to reiterate the truth, and in those, who not being informed about it, will be obliged by respect it, and by the authority of the writer, to believe in it as it behoves. And the Archbishop of Gniezno, not having as much to justify firmly

${ }^{82}$ Letter from Giacomo Rospigliosi to Galeazzo Marescotti, Rome, 17 XI 1668, AAV, Segr. di Stato, Pol. 182, fol. 95: 'Ancorche ne' tempi più antichi la pietà della Republica di Polonia e la sua degna venerazione verso il Sommo Pontefice habbia con maniera ancora di maggior decoro dato nelle Diete d'Interregno luogo, e prerogative à Nunzij Apostolici, e gli Arcivescovi Primati habbian sempre voluto dimostrarsi tali specialmente nell'honorare al maggior segno chi rappresenta principalmente il Papa'.

${ }^{83}$ Ibid.

${ }^{84}$ Letter from Giacomo Rospigliosi to Galeazzo Marescotti, Rome, 8 XII 1668, AAV, Segr. di Stato, Pol. 82, fol. 76.

${ }^{85}$ Letter from Galeazzo Marescotti to Giacomo Rospigliosi, Warsaw, 14 XI 1668, AAV, Segr. di Stato, Pol. 82, fol. 529v. 
his contrary pretensions, will be obliged to abandon them or to make them appear as supported by only violence, and by the ambition to establish useless innovations to the prejudice of the Holy See which, so it is believed considering the justice and the singular piety of this noble Republic, will not be permitted. ${ }^{86}$

Should the nuncio prove unable to retain the ceremonial dignity of the representative of the Holy See during the election Sejm, he would be allowed to abstain from participating in its deliberations and in the very act of election. The cardinal Secretary of State referred to historical precedents on this point, yet without mentioning any specific examples. Nonetheless, he might have referred to nuncio Vincenzo Lauro, who in 1575 did not take advantage of his right to a public audience at the election Sejm. ${ }^{87}$ Should he not take part in the election personally, Marescotti was supposed to consign the papal briefs to the Commonwealth through the mediation of third parties. ${ }^{88}$

Nevertheless, Marescotti continued to convey to Rome his concern regarding his participation in the deliberations of the election Sejm:

I believe it is now necessary to let Your Eminence know about the difficulty that I will encounter in being granted in public in the Senate the place which is supposed to have been assigned to Mons. De Torres in the last interregnum: As in his report, received by Mons. Fantuzzi, he says that even if it was written in

${ }^{86}$ Letter from Giacomo Rospigliosi to Galeazzo Marescotti, Rome, 8 XII 1668, AAV, Segr. di Stato, Pol. 82, fols 74v-75r: 'Imporrà loro di ridirne il vero, et in quelli, che non essendone informati saranno obligati dal rispetto, e dall'autorità di chi scrive a crederne come conviene. E Mons. Arcivescovo di Gnesna non havendo altrettanto da giustificar con fondamento la sua pretensione in contrario, sarà obligato à deporla ò a far apparire appoggiata alla sola violenza, et all'ambitione di far novità senza ragione in pregiuditio della Santa Sede, il che dalla giustitia, e pietà singolare di cotesta inclita Repubblica non è da creder che si permetta'.

${ }^{87}$ Letter from Vincenzo Lauro to Tolomeo Gallio, Warsaw, 13 XI 1575, in Teodor Wierzbowski, Vincent Laureo, évêque de Mondovi, nonce apostolique en Pologne, 1574-1578 (Warsaw: J. Berger, 1887), nr 77, pp. 271-72, 276. See: Wierzbowski, Uchańsciana, czyli zbiór dokumentów wyjaśniajacych życie i dziatalność Jakóba Uchańskiego, arcybiskupa gnieźnieńskiego, legata urodzonego, Królestwa Polskiego prymasa i pierwszego księcia, vol. V, Jakób Uchański, arcybiskup gnieźnieński, (1502-1581): monografia historyczna (Warsaw: J. Berger, 1892), p. 573.

${ }^{88}$ Letter from Giacomo Rospigliosi to Galeazzo Marescotti, Rome, 8 XII 1668, AAV, Segr. di Stato, Pol. 82, fols 74v-75r. 
Piasecki ${ }^{89}$ that in the interregnum in which Vladislaus had been elected, the Nuncio had a place in the Senate ad Levam Archiepiscopi Gnesnensis, for him a place between the Archbishops of Gniezno and Lviv was assigned, which means the most worthy place at the top, $[\ldots]$ because it was known by those who had been present, that this was the place given on other occasions to all Nuncios during interregna and this does not contradict the report of Piasecki..$^{90}$

Moreover, the Nuncio was concerned because the Archbishop of Lviv, due to his advanced age, was not expected to be present at the election, so everything seemed to indicate that Marescotti would be forced to sit at the side of the Primate. It would be therefore a symbolically weaker position than between the two hierarchs. ${ }^{91}$

\section{THE ABANDONMENT OF THE LEGATION PROJECT}

In January 1669, Clement IX definitively decided that it was impossible to send a cardinal legate to the Commonwealth. At that time in Rome the election was still expected in February. The postponement of the election to May, though, once again raised the possibility of organizing a legation. Papal doubts concerned, however, the sense of the mission itself:

It would not be possible to send the Legate, risking his dignity and the dignity of the Holy See. Moreover, it would be more than useless, as the Legate would not have an occasion to obtain any profit, or even treat; hence there would be a manifest risk that the legate would be reduced to a useless spectator, ${ }^{92}$

${ }^{89}$ Paweł Piasecki, Kronika Pawta Piaseckiego biskupa przemyślskiego, ed. by Julian Bartoszewicz (Cracow: Uniwersytet Jagielloński, 1870).

${ }^{90}$ Letter from Galeazzo Marescotti to Giacomo Rospigliosi, Warsaw 7 XI 1668, AAV, Segr. di Stato, Pol. 82, fol. 422: 'Stimo necessario partecipare hora all'Eminenza Vostra la difficoltà che io incontrarò nell'havere in publico Senato il posto, che si suppone havesse Mons. De Torres nell'ultimo Interregno: Poiché questo in una relatione da lui fatta, et havuta costì da Mons. Fantuzzi dice, che se bene si trovava registrato nel Piasecio, che nell'Interregno, in cui fù eletto Vladislao, hebbe il Nuntio il luogo in Senato ad Levam Archiepiscopi Gnesnensis; ad esso però fu assegnato il luogo in mezzo fra l'Arcivescovo di Gnesna, e Leopoli, che vuol dire il luogo più degno in cima, [...] perché si era saputo da chi si era trovato presente, che questo era il luogo dato altre volte alli Nuntij nell'Interregno e ciò non repugnava alla relatione del Piasecio'.

${ }^{91}$ Ibid., fols 422-24.

${ }^{92}$ Letter from Giacomo Rospigliosi to Galeazzo Marescotti, Rome, 9 I 1669, AAV, Segr. di Stato, Pol. 82, fol. 86v: 'Non potrebbe la persona del Legato mandarsi 
and furthermore:

That mission of the Legate is estimated not to be able to bring profit of any kind. It would not be opportune to expose such a discerning Minister of the Holy See to some very serious prejudices, and a mission lacking in decorum and fruit [of it]. ${ }^{93}$

In consequence, Marescotti received an order no longer to insist on the Primate's official request for the sending of the legation. ${ }^{94}$

Meanwhile, surprisingly, the long-awaited letter from Prażmowski, containing his official request for legation, was delivered in Rome to Orsini. By now even Orsini no longer saw any great prospects of organizing such a mission. ${ }^{95} \mathrm{He}$ announced, however, that he would personally ask Clement IX to support the Primate's request. ${ }^{96}$

Thus in mid-January 1669, Orsini presented Prażmowski's letter to the Pope during an audience. Clement IX replied definitively that he would not organize a legation, as it could not set off before mid-March, and its arrival only for the election, without any possibility to undertake negotiations preceding it, would not make great sense. From the papal perspective, the Polish-Lithuanian side had no right to complain about papal passivity. All the responsibility for the failure to send the legation was ascribed to the Primate and his delay in formally requesting it. ${ }^{97}$

avventurar molto la dignità, et il decoro della Santa Sede e quel ch'è più ancora ch'ella sarebbe affatto inutile, e che il Legato non havrebbe adito di concluder cosa di profitto, anzi né pur di trattarla; onde si concorrebbe un rischio manifesto che sì del legato medesimo obligato à non far altro che esser inutile spettatore'.

${ }^{93}$ Letter from Giacomo Rospigliosi to Galeazzo Marescotti, Rome, 12 I 1669, AAV, Segr. di Stato, Pol. 82, fol. 87r: 'La missione del Legato costa si stima non poter riuscir di profitto veruno, e che non valerebbe ad altro se non ad esporre un si riguardevole Ministro della Santa Sede a pregiuditij molto gravi di essa, senza decoro, né frutto'.

${ }^{94}$ Letter from Giacomo Rospigliosi to Galeazzo Marescotti, Rome, 9 I 1669, AAV, Segr. di Stato, Pol. 82, fols 86-87r.

${ }^{95}$ Letter from Virginio Orsini to Paolo Doni, Rome, 12 I 1669, in EFE X, nr 359, p. 79.

${ }^{96}$ Letter from Virginio Orsini to Cristoforo Masini, Rome, 12 I 1669, in EFE $\mathrm{X}$, nr 361, p. 80.

${ }^{97}$ Letter from Giacomo Rospigliosi to Galeazzo Marescotti, Rome, 19 I 1669, AAV, Segr. di Stato, Pol. 82, fols 89v-90. See also: Letter from Virginio Orsini to Cristoforo Masini, Roma, 19 I 1669, Archivio Capitolino, Archivio Orsini, I Serie, Corrispondenza familiare, diplomatica e amministrativa, vol. 249, fols 35-36v. 
As summarized by Orsini, the legate could not be considered a simple courier, 'who can put on his boots and leave immediately'. ${ }^{98}$

On 27 February 1669, Prażmowski sent a letter to Rospigliosi, in which he complained, with a great deal of insincerity, that the Pope had decided not to send a legate to Poland-Lithuania. It is so expressive that I decided to quote it here in its entirety and in the original language:

Eminentissimo.

Dal Breve Pontificio e dalla benignissima lettera di Vostra Eminenza delli 29 decorso mese ne hà ricevuto questo Clero e la maggior parte delli secolari dolore insigne sopra la dichiaratione fatta da Nostro Signore nel Breve sudetto di non voler più mandare legato a latere a favore della elettione di nuovo Rè in questo Regno, e ciò per alcuni motivi espressi in detto Breve Apostolico trà i quali per il principale si riceve quello della brevità del tempo stante che gli altri sono stati portati all'orecchio di Nostro Signore da alcuni che per lor fini privati non havevano gusto di tal missione e molto lontani da tal candore delle mie intentioni verso la gloria di Nostro Signore et il servigio della Religione, e per chiarirlo meglio mi deve testimonio Mons. Marescotti che io venutone in cognitione di questi sinistri riscontri, mi sono dichiarato subito con esso Monsignore per mezo [della] lettera mia di volergli consegnar carta bianca con mia sottoscrittione per imporla con li desiderati trattamenti, e non sarà mai che alcuno di questo Regno tanto obediente alla Santa Sede haverebbe animo di sminuire in cosa alcuna la dignità e grandezza di un Legato. Non ardisco (benché in me vive di continuo il desiderio) di farne più istanze a Nostro Signore et a Vostra Eminenza per tal missione già che è piaciuto alla Santità Sua di lasciar privo questo Regno di gratia altrettanto bisognosa quanto desiderata per il servigio della Religione. All'Eminenza Vostra ne rendo gratie humilissime per l'autorità interposta presso Nostro Signore che questo Regno periclita più che mai per le fattioni grandi de' Schismatici a fine che si degni la Santità Sua sostenerlo con le sue Santissime benedittioni. E qui à Vostra Eminenza faccio profondissima riverenza. ${ }^{99}$

Prażmowski, with deep (and undoubtedly very insincere) regret, reported that he had received the papal brief and letters from the Roman Curia, in which the official refusal in matter of the legation's sending was

${ }^{98}$ Letter from Virginio Orsini to Cristoforo Masini, Rome, 19 I 1669, Archivio Capitolino, Archivio Orsini, I Serie, Corrispondenza familiare, diplomatica e amministrativa, vol. 249, fols 35-36v: 'Che subito si puol mettere li stiveli e caminare'.

${ }^{99}$ Letter from Mikołaj Prażmowski to Giacomo Rospigliosi, Warsaw, 27 II 1669, AAV, Segr. di Stato, Nunz. Diverse 151, fols 329-30r. 
exposed. As the main reason for the fiasco, the Primate considered the lack of time for organising such an undertaking, while the issue of ceremonial uncertainties was considered by him as malevolent rumours against the legation's project and himself. Nevertheless, Prażmowski repeated his request for the legate's sending and papal blessing of the upcoming royal election. ${ }^{100}$

In April 1669, Marescottti reported on the rumours he had heard concerning the dissatisfaction of many nobles with the papal decision not to send a legation. Some perceived it as displaying a lack of interest of the Holy See in Polish-Lithuanian affairs, especially in comparison to the great interest it showed in the current war of Candia. ${ }^{101}$ The failure did not go unnoticed on the international scene. The Venetian ambassador to the Commonwealth, Giacinto Bianchi, wrote to the Curia that the Poles had committed a great error by not pushing for the organization of a legation, in consideration of the unpredictable developments of the royal election, especially in view of the presumptive Muscovite aspirations. ${ }^{102}$ Nevertheless, the storm soon died down, already in May 1669, the nuncio reported that the matter had ceased to be widely commented on in Poland-Lithuania. ${ }^{103}$

\section{CONCLUSIONS}

The conclusions of the presented analysis are somewhat surprising. It emerges that almost nobody wanted the legation. The proposal did not come from the Papacy but was an initiative of John Casimir. Why? The king wanted to facilitate the procedure of his abdication by the presence of the papal legate a latere, ensuring universal acceptance of his plans both in the Polish-Lithuanian Commonwealth and abroad. He counted on papal understanding and support for his projects. Still, Clement IX

${ }^{100}$ Ibid., fols 329-30r.

${ }^{101}$ Letter from Galeazzo Marescotti to Giacomo Rospigliosi, Warsaw, 17 IV 1669, AAV, Segr. di Stato, Pol. 82, fol. 619r.

${ }^{102}$ Letter from Giacinto Bianchi to [Giacomo Rospigliosi], Warsaw, 13 II 1669, AAV, Segr. di Stato, Pol. 182, fol. 105v.

${ }^{103}$ Letter from Galeazzo Marescotti to Giacomo Rospigliosi, Warsaw, 15 V 1669, AAV, Segr. di Stato, Pol. 82, fol. 646. 
skilfully avoided being manoeuvred into what would have been an awkward position, given the widespread opposition to John Casimir's plans. Moreover, according to the royal secretary Masini, the request to send a legation was suggested to the monarch by the French faction, 'believing that they were capable of inducing the Cardinal Legate to exclude the Muscovite [...], and by not putting forward other Catholic Princes to ensure the election of the Duke of Neuburg. ${ }^{104}$

The legation project was then supported by Virginio Orsini, the cardinal protector of the Commonwealth. For Orsini, a papal legation would be a guarantee of stability and a means of protecting Catholic interests in Poland-Lithuania, and apostolic nuncios Antonio Pignatelli and Galeazzo Marescotti, who hoped that a higher-ranked diplomat would offer them support and strengthen papal representation in Poland-Lithuania. They thus wanted to avoid political responsibility for the outcome of what promised to be a highly contentious election, and pass on responsibility for negotiating over the ceremonial conflicts with the Primate that they would inevitably face during the interregnum and election.

The Holy See feared the failure of the legation, both from the political and the ceremonial point of view. Initial papal interest and enthusiasm were quickly weakened by numerous rumours reaching Rome, that the legation would not be universally well-regarded in Poland-Lithuania, and that there were no guarantees regarding the offering of proper hospitality of the legation in loco or over the ceremonial precedence of the papal representative. ${ }^{105}$ Therefore, Clement IX preferred not to intervene, rather than to risk a bad reception of his mediation and peace-making endeavour. The idea of a papal legation to the PolishLithuanian Commonwealth was finally abandoned by Rome in October 1668, almost immediately after John Casimir's abdication. This failure indicates substantial changes with regard to the status and position of the Papacy in the post-Westphalian world. The aspirations of the Holy

${ }^{104}$ Letter from Galeazzo Marescotti to Giacomo Rospigliosi, Warsaw, 26 VII 1668, AAV, Segr. di Stato, Pol. 82, fol. 304: 'Credendo di poter impegnare il Cardinal Legato ad escludere il Moscovita [...], e non concorrendo altri Prencipi Cattolici far riuscire l'elettione del Duca di Neoburgo'.

${ }^{105}$ Letter from Galeazzo Marescotti to Giacomo Rospigliosi, Warsaw, 23 I 1669, AAV, Segr. di Stato, Pol. 83, fols 21v-22r. 
See to the role of mediator and peacemaker of the Christian world remained nothing more than a facade based on the crumbling foundation of medieval universalism. Papal reluctance to undertake any resolute political action and the considerable prolongation of decision-making processes in the Roman Curia caused, de facto, almost a paralysis in the activities of the Holy See's diplomatic service.

The legation was undoubtedly not wanted by Mikołaj Prażmowski. He was afraid of the competition a cardinal legate would provide, both concerning authority over the Polish Church and in consideration of the ceremonial aspects of the solemn events that would accompany the interregnum and election. In the light of Prażmowski's political ambitions, the presence of both a legato nato and a legato a latere within the borders of the Polish-Lithuanian Commonwealth could indeed generate new conflicts and undermine Prażmowski's authority within the Polish-Lithuanian Church. The ceremonial aspect seems to be crucial for the position of the Primate, refusing to comply with the precedence rules traditionally granted to the representatives of the Holy See during similar ceremonies, based on a generally accepted international ordum. Prażmowski emphasized the traditional qualification of the Archbishops of Gniezno as papal legati nati, standing above the ordinary nuncios in the hierarchy of Apostolic diplomacy. It seems that the Primate considered his office to be superior also with regard to the authority of legates a latere. To all this, we should add the purely political aspect: Prażmowski, sympathizing with France, was definitely afraid of Clement IX's hostility towards Louis XIV. On the other hand, the Papacy did not show itself hostile towards the French aspirations in the Commonwealth, even if it would maybe prefer another Catholic alternative on the Polish-Lithuanian throne, as Charles V, Duke of Lorraine and Bar or, especially, Christine Vasa. The fact that the character of the projected papal legation could not be considered anti-French proves the dominance of ceremonial and prestige issues for the negative attitude of ambitious Prażmowski towards it. The defensive line of the Primate, which turned out to be effective, was based on his subtle campaign to delay the legation. In this way, Prażmowski used papal indecision to defend his ecclesiastical and political supremacy in the Polish-Lithuanian Commonwealth and to continue the campaign to 
secure the election of the French-backed candidate. His victory came at a price, as Clement IX long blamed Prażmowski for the fiasco over the legation and deeply resented his insolent charge of papal passivity. ${ }^{106}$

Despite the more or less controversial mediatory and peace-making role of the Holy See in the European international relations, in the second half of the seventeenth century, it declined drastically. ${ }^{107}$ The collapse of the importance of papal diplomacy, considered as part of the Enlightenment processes of European society's secularizing was emphasized by Paolo Prodi. ${ }^{108}$ Also, according to Lucien Bély and Stefano Andretta, the decisive factor for the fall of the political Papacy was the gradual secularization of political relations after the conclusion of the Westphalian treaties. ${ }^{109}$ The fiasco of papal legation was another clear indication of the Papacy's lack of sufficient leverage in the postWestphalian world, as it was fundamentally weakened by the deep divisions between the Catholic powers of France and the Habsburgs, which Westphalia had signally failed to resolve. Nowhere was this more apparent than in Poland-Lithuania, where the battle between Catholic supporters of the Habsburgs and France over the succession had profoundly divided the republic.

\section{BIBLIOGRAPHY}

\section{Archival Sources}

Rome, Archivio Apostolico Vaticano,

Segreteria di Stato,

Germania 185;

Nunz. Diverse 27, 151;

Polonia 81, 82, 182.

${ }^{106}$ Letter from Virginio Orsini to Ludovico Fantone, Rome, 10 VIII 1669, in EFE X, nr 454, p. 99.

107 See: Heinz Schilling, 'The two Papal Souls and the Rise of an Early Modern State System', in Papato e politica, pp. 103-16 (p. 114).

108 Paolo Prodi, Diplomazia del Cinquecento. Istituzioni e prassi (Bologna: Pàtron, 1963), p. 137.

109 Andretta, L'arte della prudenza, p. 48. 
Rome, Archivio Capitolino,

Archivio Orsini, I Serie, Corrispondenza familiare, diplomatica e amministrativa, vol. 247, 249.

\section{Printed Primary Sources}

Christine de Suède et le cardinal Azzolino: Lettres inédites (1666-1668) avec une introduction et des notes par le Baron de Bildt, ed. by Carl Nils Daniel Bildt (Paris: Plon, 1899)

Elementa ad Fontium Editiones, III, Repertorium Rerum Polonicarum ex Archivo Orsini in Archivo Capitolino Romae, I pars, ed. by Wanda Wyhowska de Andreis (Rome: Istitutum Historicum Polonicum, 1961)

Elementa ad Fontium Editiones, X, Repertorium Rerum Polonicarum ex Archivo Orsini in Archivo Capitolino Romae, III pars, ed. by Wanda Wyhowska de Andreis, (Romae: Istitutum Historicum Polonicum, 1964)

Elementa ad Fontium Editiones, XVIII, Collectanea e rebus Polonicis Archivi Orsini in Archivo Capitolino Romae, II pars, ed. by Wyhowska de Andreis (Romae: Istitutum Historicum Polonicum, 1968)

Dykmans, Marc, Le Céremonial Papal de la Fin du Moyen Age à la Renaissance. II: De Rome en Avignon ou le Céremonial de Jacques Stefaneschi (Brussels: Institut Historique Belge de Rome, 1981)

Piasecki, Paweł, Kronika Pawta Piaseckiego biskupa przemyślskiego, ed. by Julian Bartoszewicz (Cracow: Uniwersytet Jagielloński, 1870)

Wierzbowski, Teodor, Vincent Laureo, évêque de Mondovi, nonce apostolique en Pologne, 1574-1578 (Warsaw: J. Berger, 1887)

\section{Secondary Works}

Andretta, Stefano, L'arte della prudenza. Teorie e prassi della diplomazia nell'Italia del XVI e XVII secolo (Rome: Biblink, 2006)

Barbiche, Bernard, De Dainville-Barbiche, Ségolène, 'Les légats a latere en France et leurs facultés aux XVI et XVII siècles', Archivum Historiae Pontificiae, 23 (1985), 93-165

Bély, Lucien, 'La médiation diplomatique au XVII siècle et au début du XVIII siècle', in Armées et diplomatie dans l'Europe di XVII siècle. Actes du Colloque de 1996. Bulletin nr 16, Paris 1992, 129-47

Czermak, Wiktor, 'Ostatnie lata życia Jana Kazimierza', in Ostatnie lata Jana Kazimierza, ed. by Adam Kersten (Warszawa: Państwowy Instytut Wydawniczy, 1972, 259-447

Dą̧browski, Janusz, 'Senat koronny wobec abdykacji Jana Kazimierza', Zeszyty Naukowe Uniwersytetu Jagiellońskiego. Prace Historyczne, 127 (2000), 39-58

Gregorowicz, Dorota, 'Stolica Apostolska wobec abdykacji Jana Kazimierza 1667-1668', Kronika Zamkowa. Roczniki, 2 (68) 2015, 139-63 
Góralski, Wojciech, 'Instytucja prymasów w Kościele katolickim', in Prymasi i prymasostwo $w$ dziejach państwa i narodu polskiego, ed. by Wiesław Jan Wysocki (Warsaw: Instytut Wydawniczy Pax, 2002), pp. 10-15

Hundert, Zbigniew, Wojsko koronne w walce stronnictwa malkontentów z ugrupowaniem dworskim 1669-1673 (Oświęcim: Napoleon V, 2014)

Kłaczewski, Witold, W przededniu wojny domowej $w$ Polsce. Walka sejmowa $z$ lat 1664-1665 (Lublin: UMCS, 1984)

, Jerzy Sebastian Lubomirski (Wrocław: Zakład Narodowy im. Ossolińskich, 2002)

Kraszewski, Igor, 'Rokosz Lubomirskiego. Tło konfliktu wewnętrznego w rzeczypospolitej XVII wieku', in Bitwa pod Mątwami. Historia i pamięć, ed. by Tomasz Łaszkiewicz (Inowrocław: Polskie Towarzystwo Historyczne Oddział w Inowrocławiu, 2017), 13-35

Matwijów, Maciej, 'Geneza abdykacji Jana Kazimierza Wazy 1662-1668', Czasopismo Zaktadu Narodowego imienia Ossolinskich, 11 (2000), 79-136

, Ostatnie sejmy przed abdykacja Jana Kazimierza 1667 i 1668 (Wrocław: Polska Akademia Nauk, Zakład Narodowy im. Ossolińskich, 1992)

Nagielski, Mirosław, Rokosz Jerzego Lubomirskiego w 1665 roku (Warsaw: Trio, 1994)

—, Druga wojna domowa w Polsce: $z$ dziejów polityczno-wojskowych Rzeczypospolitej u schytku rządów Jana Kazimierza Wazy (Warsaw: Neriton, 2011)

Ochmann, Stefania, Sejmy lat 1661-1662. Przegrana batalia o reforme ustroju Rzeczypospolitej (Wrocław: Wydawnictwo Uniwersytetu Wrocławskiego, 1977)

Ochmann-Staniszewska, Stefania, Staniszewski, Zdzisław, Sejm Rzeczypospolitej za panowania Jana Kazimierza Wazy. Prawo - doktryna - praktyka, 1 (Wrocław: Wydawnictwo Uniwersytetu Wrocławskiego, 2000)

Płaza, Stanisław, Rokosz Lubomirskiego (Warszawa: Krajowa Agencja Wydawnicza, 1996)

Prodi, Paolo, Diplomazia del Cinquecento. Istituzioni e prassi (Bologna: Pàtron, 1963) Przyboś, Adam, Michat Korybut Wiśniowiecki 1640-1673 (Kraków: Universitas, 2007) , 'Prażmowski, Mikołaj', Polski Stownik Biograficzny, XVIII/3, 1984, 382-89

Schilling, Heinz, 'The two Papal Souls and the Rise of an Early Modern State System', in Papato e politica internazionale nella prima età moderna, ed. by Maria Antonietta Visceglia (Rome: Viella, 2013), 103-16

Tallon, Alain, 'Conflicts et médiationes dans la politique internationale de la papaute', in Papato e politica internazionale nella prima età moderna, ed. by Maria Antonietta Visceglia (Rome: Viella, 2013), 117-30

-, 'Les missions de paix de la papauté au XVIe siècle', in Guerres et paix en Europe centrale aux époques moderne et contemporaine. Mélanges d'histoire des relations internationales offerts à Jean Bérenger, ed. by Daniel Tollet (Paris: Presses de l'Université Paris-Sorbonne, 2003), 165-80

Tygielski, Wojciech, Rzymu do Rzeczypospolitej. Studia z dziejów nuncjatury apostolskiej $w$ Polsce, XVI i XVII w. (Warsaw: Wydawnictwa Fundacji "Historia pro Futuro", 1992)

Wasilewski, Tadeusz, Ostatni Waza na polskim tronie (Katowice: Śląsk, 1984) 
—, Jan Kazimierz (Warszawa: Zamek Królewski, 1985)

Wierzbowski, Teodor, Uchańsciana, czyli zbiór dokumentów wyjaśniajacych życie i dziatalność Jakóba Uchańskiego, arcybiskupa gnieźnieńskiego, legata urodzonego, Królestwa Polskiego prymasa i pierwszego księcia, vol. V, Jakób Uchański, arcybiskup gnieźnieński, (1502-1581): monografia historyczna (Warsaw: J. Berger, 1892)

Wiszowata-Walczak, Katarzyna, Pietro Vidoni - nuncjusz w Rzeczypospolitej 1652-1660 (Ph.D. thesis)

Wodka, Joseph, Zur Geschichte der nationalen Protektorate der Kardinäle an der römische Kurie (Innsbruck-Leipzig: F. Rauch, 1938)

Wójcik, Zbigniew, Jan Kazimierz Waza (Wrocław: Zakład Narodowy im. Ossolińskich, 1997)

Dorota Gregorowicz - PhD, Institute of History at the Faculty of Humanities, University of Silesia in Katowice; e-mail: dorota.gregorowicz@us.edu.pl 